\title{
The Influence of Flexible Work Arrangement on Employee Behavior During the COVID-19 Pandemic in the Republic of Serbia
}

DOI: 10.7595/management.fon.2021.0026

Abstract:

Research Question: The authors investigate the impact of Flexible Work Arrangements (FWAs) on employee behavior during the COVID-19 pandemic in the Republic of Serbia. The main question is whether FWA and in which manner influences employees' behavior, especially turnover intentions and employees' engagement. Motivation: Based on the study results of Azar et al. (2018), Masuda et al. (2011), and Laurel et al. (2009), the author planned to identify the relations between FWA and the behavior of employees in terms of Engagement and Turnover intention in the Covid - 19 pandemic era. Idea: The research is created by considering the changes in the way of operating in almost all business activities caused by this pandemic. Having in mind the pandemic, and spreading of the virus after that, there is a gradual shift of work from the company's office to FWAs, especially "work from home" and teleworking. Data: The research was conducted during 2020/21, on a sample of 219 employees on whom this pandemic had a great impact and brought changes in the way of working, which became quite different from that before. Data collection is performed via an electronic survey Google-Forms, where respondents were able to answer the questions asked in the questionnaire via their electronic devices at any time. Tools: To analyze the data collected by completing the questionnaire, the author used Smart PLS 3 software to make the data analysis relevant. During the analysis of data in Smart PLS, an independent variable was formed that refers to "Flexible Work Arrangements", while the dependent variables are "Engagement" and "Turnover intentions". Findings: Based on the conducted research, we conclude that "FWAs" have a positive impact on the Engagements of employees in the Republic of Serbia and a negative impact on Turnover intentions. All hypotheses are confirmed. Contribution: The paper contributes to the literature by empirically testing how certain factors affect the behavior of employees in the Republic of Serbia during the COVID - 19 pandemic.

Keywords: COVID-19 pandemic, flexible working arrangements, engagement, turnover intentions, Serbia

\section{Introduction}

The labor market has significantly changed in the last decade due to different changes and challenges. The processes of globalization, digitalization, competitiveness, dynamism, and the presence of new generations ( $\mathrm{Y}$ and $\mathrm{Z}$ generation) in the companies, lack of skilled workers in many countries of the world are "new normal" in the business world. Companies that want to attract and retain talents, as well as to increase their knowledge, skills, and abilities (KSA), need to become increasingly flexible and innovative in terms of the organization of work, work-life balance, training, compensation systems, and development programs, career management, etc. (Berber \& Slavic, 2019).

At the end of 2019, a new form of Corona virus, which is responsible for the severe respiratory disease COVID-19, broke out, which quickly turned into a public health crisis and changed the direction of the global 
economy into the deepest recession as during the Great Depression (OCDE, 2020, p. 24). On March 11, 2020, the World Health Organization (WHO) qualified public health as an emergency situation caused by COVID-19 disease as an international pandemic. (World Health Organization, 2020).

Millions of employees around the world are going through a difficult time of redefined work. Since the outbreak of the COVID-19 pandemic, there has been a change in the working environment overnight and all employees have had to adapt quickly to the new situation. It seems that the challenges of managing family affairs, business duties as well as personal security are not simple, and, on the contrary, day by day, workers are facing new challenges and problems in various fields. The COVID-19 pandemic has significantly transformed the work environment as well as the work responsibilities of many individuals who started working from home or remote working. In addition to distance work, a new problem has arisen: many families have faced a situation in which they had to assist their children who were also "imprisoned" at home and attended distance learning classes during that period (Thulin, Wilhelmson, \& Johansson, 2019). The way they cope with these challenges caused by the COVID-19 pandemic will have profound consequences on employee productivity as well as on the success of any company (Vasic, 2020).

As a result of their intention to become more flexible, but also as a response to the Covid19 pandemic, many organizations switch from office work to different ways of FWAs, mostly home-based work and teleworking. FWAs offer the ability to employees to make changes on where, when and the total time they would spend or engage in work-related tasks, and they are usually used as part of the human resource strategy to attract, motivate and retain key talents (Richman, et al., 2008).

(Richman et al., 2008; Choo et al. 2016; Azar et al., 2018). Many of FWAs were found to have positive relations to employees and firm productivity (Richardson, \& McKenna, 2014), and employees' behavior in terms of engagement (Ugargol \& Patrick, 2018), commitment (Choo et al., 2016), innovative behavior, satisfaction (Wheatley, 2017), etc. In contrast, FWAs are found to have negative relations to employees' turnover and absenteeism (Berber \& Slavic, 2019). Based on the above-mentioned, the authors developed a research aim. This research aims to investigate the relations between the usage of FWAs and employees' engagement and turnover intentions. Many managers must be familiar with FWAs that formalize where, when and how employees do their job (Chen \& Fulmer, 2018). It has been established that working from home and flexible work scheduling bring benefits to employee health (Anderson, Kaplan \& Vega, 2015). International human resource management (IHRM) has a unique vision concerning FWAs, where for example employees working in global teams are accustomed to work from home and outside normal working hours. The survey, launched in March 2020, with 800 global human resource managers, revealed that $88 \%$ of employees in the organization were either encouraged or required to work from home during the COVID-19 pandemic crisis. For employees who were mobile globally and are now away from home during the COVID19 pandemic, the change is particularly significant and the boundaries between family and work may require renegotiation and reorganization (Caligiuri, De Cieri, Minbaeva, Verbeke \& Zimmermann, 2020). The COVID19 pandemic and the accompanied measures have the potential to affect a series of work- and career-related variables: working conditions, work motivations and behavior, job and career attitudes, career development, and personal health and well-being (Spurk \& Straub, 2020). One very important fact that is confirmed to be true at the time of the COVID -19 pandemic is that people must be aware of the weight this pandemic brings to both people's private lives and the business world. That is why it is very important for employees to be aware of all the problems that this pandemic can cause; it is important that the work is well organized so that the consequences are as small as possible (Prasetyo et al., 2020).

The research in this paper was conducted during 2020/21, on a sample of 219 employees on whom this pandemic had a substantial impact and brought changes in the way of working, which was quite different than before. Data collection is performed via an electronic survey Google-Forms, where respondents were able to answer the questions asked in the questionnaire via their electronic devices at any time. Tools: To analyze the data collected by completing the questionnaire, the author used Smart PLS 3 software to make the data analysis relevant.

The paper is structured as follows: The first part contains an overview of the relevant structure related to flexible working arrangements, types of Flexible Work Arrangements, relations between Flexible Work Arrangements and employee engagement, relations between Flexible Work Arrangements, and turnover intentions. The second part refers to the research methodology where it is described how the research was conducted (which questionnaires were used, what are the many parts the questionnaire consists of, how many people filled in the questionnaire, how to answer the questions from the questionnaire, etc.). The third part of the paper refers to the results of the research and the discussion of the obtained results. Finally, the final part of the paper refers to the concluding observations and gives recommendations for future research. As a result of the lack of literature and understanding of telework at the time of the COVID-19 pandemic, the 
paper seeks to clarify in more detail the impact of the pandemic on employee behavior. In that sense, this study aims to characterize the remote work that was conducted in the Republic of Serbia in the context of the COVID-19 pandemic.

\section{Theoretical Background}

\subsection{Flexible work arrangements and teleworking}

FWA are practices such as working from home, working outside regular working hours, reduced as well as extended contract hours (Den Dulk, Groeneveld, Ollier-Malaterre, \& Valcour, 2013, Stirpe \& Zárraga-Oberty, 2017). Firms offer FWA to support employees to balance their work and private lives but also to improve firm performance (Richardson, \& McKenna, 2014). Also, FWAs are an adequate response of companies in relation to dual-earner couples, women, and single-parent families, as well as those who have geriatric care responsibilities, in the workplace (Choo et al., 2016, p. 24). FWAs are "working patterns involving modifications to the regular working hours such as work at nights and at weekends, home-based working, teleworking, part-time jobs, flexitime, compressed work weeks, etc. (Stavrou, 2005; Berber \& Slavic, 2019).

Table 1: Types of FWA according to Cranet international research methodology

\begin{tabular}{|c|c|}
\hline Weekend work & $\begin{array}{l}\text { Employees can extend working hours during the weekend } \\
\text { or can work in two shifts during Saturday and Sunday with } \\
\text { free time during the rest of the week. }\end{array}$ \\
\hline Work in shifts & $\begin{array}{c}\text { Employees are replaced in job positions so that the } \\
\text { company can work longer than the working hours of } \\
\text { individual employees. }\end{array}$ \\
\hline Overtime & $\begin{array}{l}\text { Employees work additional hours during the day, weekly, or } \\
\text { over a year provided for in their employment contracts. }\end{array}$ \\
\hline Hourly contracts & $\begin{array}{l}\text { Employees perform a predetermined number of working } \\
\text { hours per year, with the division of hours being based either } \\
\text { on an agreement between the employed workers and the } \\
\text { employer or the basis of the last need for market demands. }\end{array}$ \\
\hline Part-time work & Employed workers regularly work less than a whole week. \\
\hline Division of labor & $\begin{array}{l}\text { Division of labor Two part-time employees share one full- } \\
\text { time job. }\end{array}$ \\
\hline Flexible working hours & $\begin{array}{l}\text { Employees work full time by being able to choose the start } \\
\text { and end of working hours within the limits set by the } \\
\text { company's management. }\end{array}$ \\
\hline Temporary employment & Employment is offered temporarily \\
\hline Fixed-term contracts & $\begin{array}{l}\text { Employees work under short-term or long-term employment } \\
\text { contracts with a fixed duration. }\end{array}$ \\
\hline Work from home & Employees work from home. \\
\hline Teleworking & $\begin{array}{c}\text { Employees work separately from the office throughout the } \\
\text { work week, while maintaining an electronic presence in the } \\
\text { office. }\end{array}$ \\
\hline
\end{tabular}

Source: (Stavrou, Parry \& Anderson, 2015.; Berber \& Slavic, 2019, p. 35).

With the adoption of advanced electronic media and the Internet, working from home and working remotely is becoming increasingly popular among companies around the world. It is estimated that about $10 \%$ of companies in Spain and about $50 \%$ of companies in the US, Germany and the UK use telecommuting as a work arrangement. In Japan, 13\% of companies have signed a law that allows employees to work from home; the bill is known as the Republic Act No. 11165 or the Telecommuting Act (Ramos \& Prasetyo, 2020). 
Over the past years, there has been a significant increase in the number of workers who have come to apply for flexible working arrangements (at least 17\% in Europe and $16 \%$ in the US in the last year). As the most flexible type of work arrangement, online platform mediated contracting has more flexibility compared to regular work arrangements. Gig work is a type of temporary contract work that connects self-employed workers directly with clients via a digital platform (Spurk \& Straub, 2020). Flexible work arrangements have a positive effect on attracting and retaining employees, which contributes to the better work performance of the company (Sharafizad, Paull \& Omari, 2011).

Based on different legal regulations and theoretical approaches, FWAs can have multiple meanings in different countries around the world. According to Cranet International Research Methodology, the measures of FWA are as follows:

It was found that FWAs have a positive impact on employee engagement, increased productivity, the financial performance of companies, customer satisfaction, increase in quality, employee satisfaction, commitment, etc. (Richardson, \& McKenna, 2014; Ugargol \& Patrick, 2018; Berber \& Slavic, 2019; Weideman \& Hofmeyr, 2020).

As one of the very interesting FWAs, that is increasingly offered, teleworking is defined as "Flexible Work Arrangements" which means that employees work at a location that is far from the company's headquarters or production facility; it also refers to the fact that the worker has no personal contact with associates there but there is an opportunity to communicate using the modern technologies such as mobile phones, laptops, etc. (Wang, Liu, Qian, \& Parker, 2020). Teleworking is not a new thing and many companies around the world have embraced this way of working, but not to a large extent. This way of working is mainly used in education and health, information and communication as well as in large companies (Pigini \& Staffolani, 2019). Teleworking implies that the employee is available anywhere and at any time and thus meets the requirements of the organization (Baruch, 2000). Teleworking is already an established work practice in most countries and is thought to become more prevalent in the next few years. Today, in the era of computers and interns, teleworking has become something that most companies will be able to afford (Heleta, 2010). However, this type of FWA (teleworking) was not widely used in practice before the outbreak of the pandemic (Kossek \& Lautsch, 2018). Besides teleworking, working from home, or home-based work became a "new norm" for many employees during the COVID-19 pandemic. Millions of people took refuge in their place by staying at home and working remotely connecting with colleagues via email, mobile phones, and video conferencing via the Internet. But what will happen after the end of the crisis? Will we return to the "old normal" ways of working or will employers recognize working from home as a benefit to both them and employees? (Tavares, Santos, Diogo, \& Ratten, 2020).

\subsection{Relations between Flexible Work Arrangements and Employee Engagement}

Employee engagement has gained global interest from practitioners and researchers, as organizations recognize the positive impact and competitive advantage that engaged employees (Kahn \& Heaphy, 2014). Employee engagement results in the enhancement of various performance outcomes for organizations. These include productivity, financial considerations, customer satisfaction, a decrease in employee absenteeism, and an increase in overall product/service quality (Bakker \& Demerouti, 2007). The benefits associated with employee engagement seem evident in literature and have become an important topic in the business world (Hammer, Neal, Newsom, Brockwood \& Colton, 2005). Due to rapid changes in workforce diversity and changes in the way work is delegated and performed, there is a growing need for a proactive response by the company to work to ensure employee engagement that is a key tool for increasing productivity (Parkes \& Langford, 2008). Companies are currently increasingly facing various challenges in managing a diverse workforce by working on support policies as well as employee programs that have a positive impact on employee engagement (Myers \& Dreachslin, 2007).

The impact of FWAs on employee engagement has a positive effect on employees, as shown in the author's work (Ugargol \& Patrick, 2018) where the study showed that the application of flexible options to employees has potential benefits and that this type of arrangement ensures work-life balance of the employees. Workers are more engaged using these options that the company offers them. Similarly, in the work of the author (Weideman \& Hofmeyr, 2020), it has been found found that Flexible Working Arrangements (Flextime, Flexplace, and Compressed Work week) have a positive impact on employee engagement and thus lead to increased productivity, financial performance, customer satisfaction, increase in quality. In the work of the authors (Richman, Civian, Shannon, Hill \& Brennan, 2008) results indicate that perceived flexibility and supportive work-life policies have significant independent effects in predicting employee engagement and expected retention even after controlling for several personal, family, and job characteristics.

H1: Flexible work arrangements are positively related to employee engagement. 


\subsection{Relations between Flexible Work Arrangements and Turnover Intentions}

Previous studies involving Anglo samples have shown that FWAs availability is negatively related to turnover intentions (Allen, 2001; Batt \& Valcour, 2003; McNall et al., 2010). Specifically, Allen (2001) found that flexible benefits were positively related to job satisfaction and negatively related to Turnover intentions; Batt and Valcour (2003) showed that flextime availability was negatively related to turnover intentions, and McNall et al. (2010) found that flextime and compressed work week availability were negatively related to lower turnover intentions. In the work of the authors (Masuda, Poelmans, Allen, Spector Lapierre, Cooper, Abarca, Brough, Ferreiro \& Fraile, 2011, p. 18) it has been found that FWA negatively affects the turnover intentions of workers to leave companies when using FWA in business. Also, in the sample of 9 CEE countries, Berber \& Slavic (2019) found that FWA bundle that consists of home-based work and teleworking had a negative relation to employees' turnover which means that a higher usage of this kind of FWA reduces employees' decision to leave the company. Anderson \& Kelliher (2009) came up with the conclusion that FWAs increased the feelings and loyalty of the employees because they can meet their requirements, especially their personal needs, and this automatically affects the increase of their satisfaction and greater commitment at work. Companies are beginning to acknowledge that FWAs can retain talented employees and reduce their turnover intention. Research by Grover \& Crooker (1995) also succeeded in proving that employees of organizations that provide flexible working hours had much lower turnover intentions. In contrast, studies by Fathi et al. (2020) found that FWAs were not significantly related to turnover intentions. This may be true in countries with collective cultures. Research by Timms et al. (2015) found that flexible work arrangements are highly dependent on cultural norms in the workplace. A study by Masuda et al. (2011) found that flexible work arrangements were not particularly respected or valued in collective countries (Lutfiani, Singh, Rashid \& Arumugam, 2020).

H2: Flexible working arrangements are negatively related to turnover intentions.

\section{Methodology}

\subsection{The questionnaire}

During the process of research and analysis of the impact of the COVID-19 pandemic on employee behavior when using FWA, primarily work from home, a combination of questionnaires was used. The first part of the questionnaire refers to control questions such as gender, age structure, level of education, position in the company, sector to which your company belongs by activities, size of organization and affiliation to public or private sector, market that your company serves. The second part of the questionnaire deals with questions related to the independent variable "Flexible Work Arrangements" and it consists of 11 questions:

Table 2: Questionnaire about Flexible Work Arrangements

\begin{tabular}{|c|l|c|}
\hline 1. & FWAs help me to balance life obligations. & (FWA1) \\
\hline 2. & I can't afford the loss of earnings associated with most flexible work options. (R) & (FWA2R) \\
\hline 3. & $\begin{array}{l}\text { FWAs do not suit me because they make me feel disconnected from the } \\
\text { workplace. (R) }\end{array}$ & (FWA3R) \\
\hline 4. & $\begin{array}{l}\text { Shorter working hours would negatively affect my career progress in the company } \\
\text { where I work. (R) }\end{array}$ & (FWA4R) \\
\hline 5. & $\begin{array}{l}\text { Working with more flexible working hours is essential for me to fulfill family } \\
\text { obligations. }\end{array}$ & (FWA5) \\
\hline 6. & FWAs are essential to me when participating in family and social events. & (FWA6) \\
\hline 7. & FWAs allow me to focus more on work than when I am at work. & (FWA7) \\
\hline 8. & People in my workplace react negatively to people who use FWAs. (R) & (FWA8R) \\
\hline 9. & People who use FWAs are usually less committed to their work role. (R) & (FWA9R) \\
\hline 10. & $\begin{array}{l}\text { People who use FWAs often miss important work events or communications such } \\
\text { as meetings, training, important announcements, etc. (R) }\end{array}$ & (FWA10R) \\
\hline 11. & I would not be able to do a paid job at all if I could not use FWAs. & (FWA11) \\
\hline
\end{tabular}

Source: Albion, 2004.

The third part of the questionnaire refers to the dependent variables and questions related to them. The first dependent refers to "Engagement" and it consists of 9 questions: 
Table 3: Questionnaire about Engagement

\begin{tabular}{|c|l|c|}
\hline $\mathbf{1 .}$ & I feel bursting with energy at work. & (ENG1) \\
\hline $\mathbf{2 .}$ & I feel strong and lively at work. & (ENG2) \\
\hline 3. & I am enthusiastic about my job. & (ENG3) \\
\hline 4. & My job inspires me. & (ENG4) \\
\hline $\mathbf{5 .}$ & When I get up in the morning, I feel like going to work. & (ENG5) \\
\hline $\mathbf{6 .}$ & I am happy when I work intensively. & (ENG6) \\
\hline $\mathbf{7 .}$ & I am proud of the job I do. & (ENG7) \\
\hline $\mathbf{8 .}$ & I am completely focused on my job. & (ENG8) \\
\hline $\mathbf{9 .}$ & I get carried away when I work. & (ENG9) \\
\hline
\end{tabular}

Source: Schaufeli, Bakker \& Salanova, 2006.

The second dependent relates to "Turnover intentions" and this part consists of 4 questions:

Table 4: Questionnaire about Turnover intentions

\begin{tabular}{|c|l|c|}
\hline $\mathbf{1 .}$ & I often think about leaving my current job. & (TI1) \\
\hline 2. & $\begin{array}{l}\text { Maybe next year I will leave my current company and start working } \\
\text { for someone else. }\end{array}$ & (TI2) \\
\hline 3. & I plan to stay in this company for a longer time to develop my career. (R) & (TI3R ) \\
\hline 4. & I probably won't have a bright future if I stay in this company. & (TI4) \\
\hline
\end{tabular}

Source: Chen \& Francesco, 2000.

The assessment was conducted as follows: the respondents responded to the questions asked by marking the offered fields below each of the questions asked in the questionnaire. In response to the difficulty of measuring character and personal traits, Likert developed a procedure for measuring attitudes through a scale (Boone \& Boone, 2012).

Respondents answered the questions in the questionnaire based on the Likert scale in the range of $1-5$. (1 $=$ Strongly disagree, $5=$ Strongly Agree).

\subsection{The sample}

The research was conducted through the electronic questionnaire "Google forms". The questionnaire is intended primarily for people who are employed and whose business and private life was affected by this pandemic. The link to the electronic questionnaire was primarily distributed to people the authors know personally, who move in the business world and who belong to different sectors, those in which this type of flexible work arrangement "work from home" is most present, such as education, finance, and employment. insurance, professional, scientific, innovation and technical activities, trade sector, etc.

The questionnaire was filled out by 219 employees throughout the Republic of Serbia, and data collection was performed from December 2020 to February 2021. The main part of the sample consists of female respondents $(57.99 \%)$, while the rest of the respondents belong to the male population (42.01\%). Regarding the age structure of the respondents, the largest number of them belong to the ages between 25-34 (36.99\%), while the smallest number of them belong to the population over 55 years of age (7.76\%). Based on the completed questionnaires, the largest number of respondents have completed master studies $(36.07 \%)$, and this percentage is close to the number of respondents who have completed a bachelor degree $(35.16 \%)$. It should be emphasized that out of a total of 219 respondents, as many as 25 of them have completed Ph.D. studies (11.42\%), while the smallest number of respondents have completed three years of vocational studies $(2.74 \%)$. As for the position in the company where the employees work, the largest number of respondents belong to professional workers $(53.42 \%)$, while the smallest number of them are manual workers $(4.11 \%)$. The largest percentage of respondents belongs to Sector K. Financial and insurance activities (15.07\%), while the smallest number of them belong to Sector R. Arts, entertainment and recreation $(0.46 \%)$. Based on the completed questionnaires, we conclude that the largest number of respondents belong to the medium size of the organization $(38.81 \%)$ while the smallest number of them belong to the large size of the organization (26.03\%). The main part of the sample belongs to the private sector $(65.3 \%)$ while the rest of the respondents belong to the public sector (34.7\%). Most of the respondents answered that their company serves the National market $(27.85 \%)$, while the smallest number of them serve the global market (12.79\%). Most of the respondents have answered that the headquarters of their company is in the Republic of Serbia (78.54\%), whereas the smallest number of them answered that the company's 
headquarters are in a country that is not a member of the EU (2.28\%). The largest number of respondents indicate that the company in which they work is national $(67.58 \%)$, while the smallest number of them indicate that they work in a subsidiary of a national company $(5.02 \%)$.

Table 5: Sample characteristics

\begin{tabular}{|c|c|c|c|}
\hline & Sample Carasteristics & $N$ & $\begin{array}{l}\text { Percentage } \\
\text { of sample }\end{array}$ \\
\hline & Gender & 219 & 100 \\
\hline 1 & Male & 92 & 42.01 \\
\hline \multirow[t]{2}{*}{2} & Female & 127 & 57.99 \\
\hline & Age & 219 & 100 \\
\hline 1 & Fewer than 25 & 42 & 19.18 \\
\hline 2 & $25-34$ & 81 & 36.99 \\
\hline 3 & $35-44$ & 45 & 20.55 \\
\hline 4 & $45-55$ & 34 & 15.53 \\
\hline \multirow[t]{2}{*}{5} & More than 55 & 17 & 7.76 \\
\hline & Education & 219 & 100 \\
\hline 1 & High School & 19 & 8.68 \\
\hline 2 & Three-year vocational studies & 6 & 2.74 \\
\hline 3 & Bachelor & 77 & 35.16 \\
\hline 4 & Master study & 79 & 36.07 \\
\hline 5 & Master (Serbian version) & 13 & 5.94 \\
\hline \multirow[t]{2}{*}{6} & Ph.D. study & 25 & 11.42 \\
\hline & Possition in Company & 219 & 100 \\
\hline 1 & Manager & 60 & 27.4 \\
\hline 2 & Professional worker & 117 & 53.42 \\
\hline 3 & Administrative worker & 33 & 15.07 \\
\hline \multirow[t]{2}{*}{4} & Manuel worker & 9 & 4.11 \\
\hline & Sector & 219 & 100 \\
\hline 1 & Sector A. Agriculture, forestry and fishing & 4 & 1.83 \\
\hline 2 & Sector B. Mining & 0 & 0 \\
\hline 3 & Sector C. Manufacturing & 24 & 10.94 \\
\hline 4 & Sector D. Electricity, gas, steam and air conditioning supply & 4 & 1.83 \\
\hline 5 & $\begin{array}{l}\text { Sector E. Water supply, wastewater management, control of } \\
\text { waste disposal processes and similar activities }\end{array}$ & 0 & 0 \\
\hline 6 & Sector F. Construction & 7 & 3.2 \\
\hline 7 & $\begin{array}{l}\text { Sector G. Wholesale trade, retail trade, repair of motor } \\
\text { vehicles and motorcycles }\end{array}$ & 17 & 7.76 \\
\hline 8 & Sector H. Transport and storage & 8 & 3.65 \\
\hline 9 & Sector I. Accommodation and catering services & 5 & 2.28 \\
\hline 10 & Sector J. Information and communication & 7 & 3.2 \\
\hline 11 & Sector K. Financial and insurance activities & 33 & 15.07 \\
\hline 12 & Sector L. Real Estate & 0 & 0 \\
\hline
\end{tabular}




\begin{tabular}{|c|c|c|c|}
\hline & Sample Carasteristics & $\mathbf{N}$ & $\begin{array}{l}\text { Percentage } \\
\text { of sample }\end{array}$ \\
\hline & Sector & 219 & 100 \\
\hline 13 & $\begin{array}{l}\text { Sector M. Professional, scientific, innovation and technical } \\
\text { activities }\end{array}$ & 27 & 12.33 \\
\hline 14 & Sector N. Administrative and support service activities & 2 & 0.91 \\
\hline 15 & $\begin{array}{l}\text { Sector O. Public administration and defense, compulsory } \\
\text { social security }\end{array}$ & 10 & 4.57 \\
\hline 16 & Sector P. Education & 42 & 19.18 \\
\hline 17 & Sector Q. Health and Social Welfare & 9 & 4.11 \\
\hline 18 & Sector R. Arts, entertainment and recreation & 1 & 0.46 \\
\hline 19 & Sector S. Tourism & 7 & 3.2 \\
\hline 20 & Sector T. Activities of households as employers & 0 & 0 \\
\hline 21 & Sector U. Activities of extraterritorial organizations and bodies & 0 & 0 \\
\hline \multirow[t]{2}{*}{22} & Sector W. Other service activities & 12 & 5.48 \\
\hline & The size of the organization & 219 & 100 \\
\hline 1 & Small & 77 & 35.16 \\
\hline 2 & Medium & 85 & 38.81 \\
\hline \multirow[t]{2}{*}{3} & Large & 57 & 26.03 \\
\hline & Belonging to the public or private sector & 219 & 100 \\
\hline 1 & Public sector & 76 & 34.7 \\
\hline \multirow[t]{2}{*}{2} & Private sector & 143 & 65.3 \\
\hline & The market that your company serves & 219 & 100 \\
\hline 1 & Local & 36 & 16.44 \\
\hline 2 & Regional & 40 & 18.26 \\
\hline 3 & National & 61 & 27.85 \\
\hline 4 & International & 54 & 24.66 \\
\hline \multirow[t]{2}{*}{5} & Global & 28 & 12.79 \\
\hline & Your company is headquartered in: & 219 & 100 \\
\hline 1 & Republic of Serbia & 172 & 78.54 \\
\hline 2 & EU & 29 & 13.24 \\
\hline 3 & A non-EU country & 5 & 2.28 \\
\hline 4 & USA & 7 & 3.2 \\
\hline \multirow[t]{2}{*}{5} & Other & 6 & 2.74 \\
\hline & Your organization is: & 219 & 100 \\
\hline 1 & National company & 148 & 67.58 \\
\hline 2 & A subsidiary of a national company & 11 & 5.02 \\
\hline 3 & An international company & 26 & 11.87 \\
\hline 4 & A subsidiary of an international company & 34 & 15.53 \\
\hline
\end{tabular}




\section{Results}

The analysis was divided into two parts. First, the author investigated the measurement model. Second, the investigation of the proposed hypotheses was performed.

Table 6: Descriptive Statistics for each indicator in study

\begin{tabular}{|l|c|c|c|c|c|}
\hline & $\mathbf{N}$ & Min & Max & Mean & Std. Deviation \\
\hline Flexible Work Arrangements & 219 & 1.91 & 4.82 & 3.64 & 0.69 \\
\hline Engagement & 219 & 2.22 & 5 & 4.21 & 0.68 \\
\hline Turnover intentions & 219 & 1 & 5 & 1.98 & 1.00 \\
\hline Valid N (listwise) & 219 & & & & \\
\hline
\end{tabular}

For the purpose of the first step, the authors analyzed reflective indicator loadings, internal consistency reliability, convergent validity, and discriminant validity. This type of measurement is proposed for reflective constructions in the model (Hair, Risher, Sarstedt \& Ringle, 2019; Grubor, Berber, Aleksic, Bjekic, 2020). In addition to the above methods, the bias of the usual method (CMB) was performed. The lowest eligibility limit for factor loading is 0.708 (Berber, N., Slavic, A., \& Aleksic, 2020). Factors with a load between 0.4 and 0.7 should be maintained if their elimination does not have a positive impact on AVE and Composite Reliability (Hair, Sarstedt, Hopkins \& Kuppelwieser, 2014).

However, certain questions were removed from the analysis because their loads were very low or even with a minus sign. Based on the above, the authors kept items with a load above the threshold of 0.708 (see Figure 1).

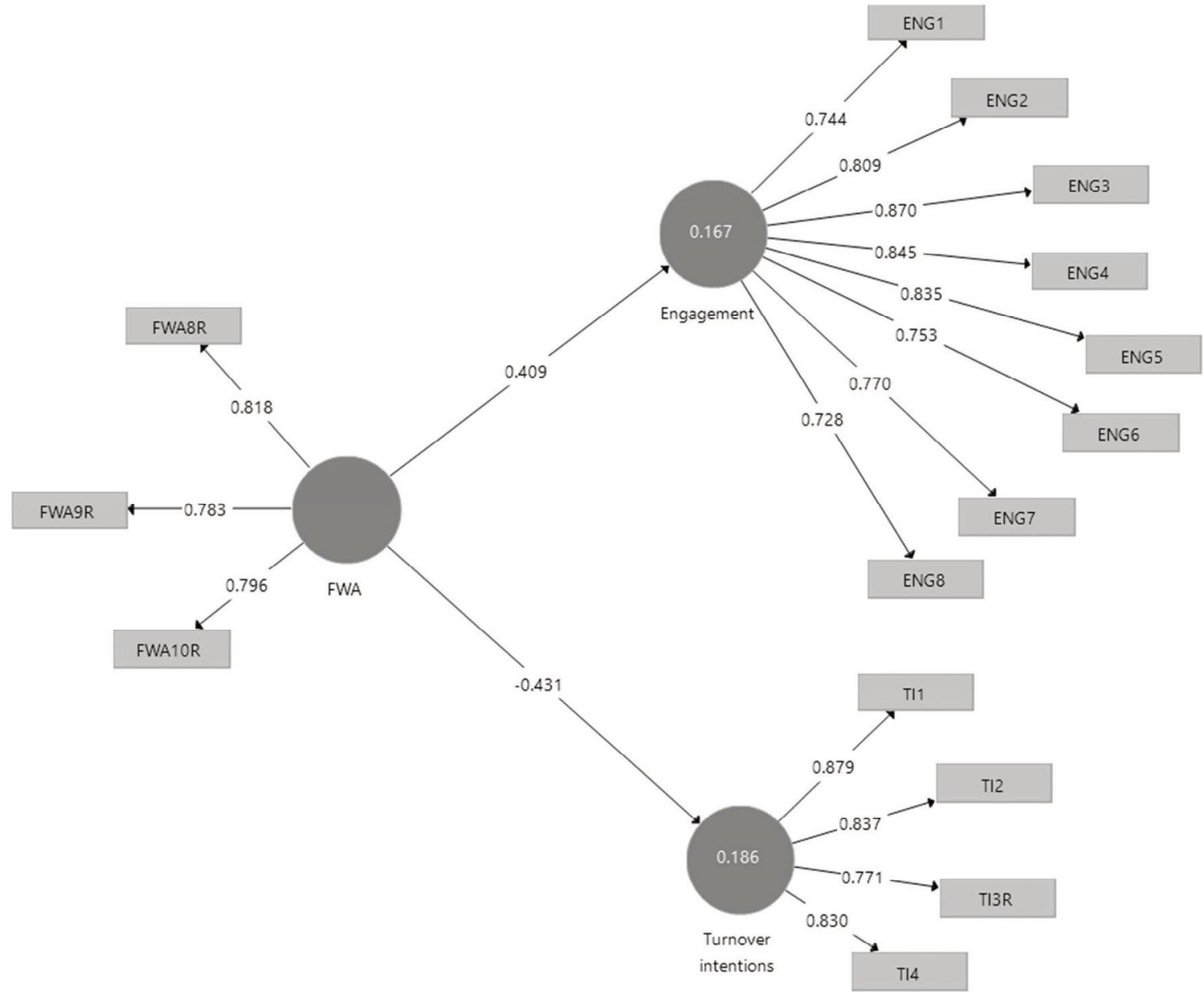

Figure 1: Path coefficient estimates

Source: Authors' own research 
Table 7: Indicator reliability and construct reliability and validity

\begin{tabular}{|c|c|c|c|c|}
\hline & Cronbach's Alpha & rho_A & Composite Reliability & Average Variance Extracted (AVE) \\
\hline Engagement & 0.917 & 0.924 & 0.932 & 0.633 \\
\hline FWA & 0.732 & 0.768 & 0.842 & 0.639 \\
\hline Turnover intentions & 0.851 & 0.858 & 0.898 & 0.689 \\
\hline
\end{tabular}

Source: Authors' calculation

The reliability test was performed by calculating Cronbach's alpha, Composite reliability, and Average Variance Extracted (AVE) (Bjekic et al., 2020). Table 7 above, which is above the text, presents the results of this sample and shows that the values of Cronbach's alpha ranged from 0.732 Flexible Work Arrangements, 0.851 Turnover intentions, and Cronbach's alpha maximum value of 0.917 Engagement. Some of the authors recommend that the lowest acceptability limit of Cronbach's alpha be 0.6 (Dakduk, González \& Portalanza, 2019).

The value of Composite reliability of constructs (CR) ranges from 0.842 Flexible Work Arrangements, 0.898 Turnover intentions and the highest value (CR) of 0.932 belons to Engagement. The lowest acceptability limit for Composite reliability of constructs (CR) is 0.7 (Hair et al., 2014. page 7); based on this value we conclude that the results shown in Table 5 indicate that the criterion (CR) is met. Composite reliability can be used as an alternative because the value of CR is slightly higher than Cronbach's alpha, and this difference is relatively insignificant (Peterson \& Kim, 2013 according to Bjekic et al., 2020, p. 7).

Convergent validity was assessed by testing the AVE variance (Average Variance Extracted). In the presented model, AVE values range from the lowest value of 0.633 Engagement, 0.639 Flexible Work Arrangements to the highest value of AVE which is 0.689 Turnover intentions. The accepted lower limit of acceptability is 0.5 (Fornell \& Lacker, 1981). Based on this lower limit, we conclude that Convergent validity is satisfied in all three constructs.

Discriminant validity can be assessed using Cross-loadings indicators, Fornell \& Larcker criteria, and Heterotrait-monotrait (HTMT) correlation rations (Ab Hamid, Sami \& Sidek, 2017).

Table 8: Discriminant validity (Cross-loadings)

\begin{tabular}{|c|c|c|c|}
\hline & Engagement & FWA & Turnover intentions \\
\hline ENG1 & $\mathbf{0 . 7 4 4}$ & 0.27 & -0.396 \\
\hline ENG2 & $\mathbf{0 . 8 0 9}$ & 0.333 & -0.409 \\
\hline ENG3 & $\mathbf{0 . 8 7}$ & 0.351 & -0.505 \\
\hline ENG4 & $\mathbf{0 . 8 4 5}$ & 0.386 & -0.546 \\
\hline ENG5 & $\mathbf{0 . 8 3 5}$ & 0.362 & -0.496 \\
\hline ENG6 & $\mathbf{0 . 7 5 3}$ & 0.317 & -0.356 \\
\hline ENG7 & $\mathbf{0 . 7 7}$ & 0.275 & -0.586 \\
\hline ENG8 & $\mathbf{0 . 7 2 8}$ & 0.278 & -0.378 \\
\hline FWA10R & 0.285 & $\mathbf{0 . 7 9 6}$ & -0.289 \\
\hline FWA8R & 0.415 & $\mathbf{0 . 8 1 8}$ & -0.432 \\
\hline FWA9R & 0.231 & $\mathbf{0 . 7 8 3}$ & -0.266 \\
\hline TI1 & -0.515 & -0.318 & $\mathbf{0 . 8 7 9}$ \\
\hline TI2 & -0.406 & -0.275 & $\mathbf{0 . 8 3 7}$ \\
\hline TI3R & -0.554 & -0.398 & $\mathbf{0 . 7 7 1}$ \\
\hline TI4 & -0.421 & -0.399 & $\mathbf{0 . 8 3}$ \\
\hline
\end{tabular}

Source: Authors' calculation

The measurement model has adequate discriminant validity when the load of the indicator is higher for its constructive structure than any construction (Chin, 1998). The results presented in Table 8 indicate that the load of each block is heavier than that of any other block in the same rows as the columns, clearly separating each latent variable. The cross-loading output confirms the discriminant validity of the measurement model.

Table 9: Discriminant Validity - (Fornell-Larcker Criterion)

\begin{tabular}{|c|c|c|c|}
\hline & Engagement & FWA & Turnover intentions \\
\hline Engagement & $\mathbf{0 . 7 9 6}$ & & \\
\hline FWA & 0.409 & $\mathbf{0 . 7 9 9}$ & \\
\hline Turnover intentions & -0.578 & -0.431 & $\mathbf{0 . 8 3}$ \\
\hline
\end{tabular}

Based on the Fornell-Larcker criterion, the root of the AVE latent variable must have a higher value than all correlations with the latent variable. (Fornell \& Larcker, 1981. page 39). In Table 8 the discriminant validity is satisfied because the value of the AVE root on the diagonal is higher than all the values below for each variable shown. 
Table 10. Discriminant Validity - Heterotrait-monotrait - HTMT -

\begin{tabular}{|c|c|c|c|}
\hline & Engagement & FWA & Turnover intentions \\
\hline Engagement & & & \\
\hline FWA & 0.464 & & \\
\hline Turnover intentions & 0.645 & 0.501 & \\
\hline
\end{tabular}

Source: Authors' calculation

The value of HTMT raids below 0.9 indicates that the defined components differ from each other to a sufficient extent, which means that they describe different phenomena (Hair et al. 2019, p. 15). The results presented in Table 9 show that all values are below 0.9 , so we can conclude that the criterion of discriminant validity is met.

The Common method (CMB) bias is detected using a complete collinearity assessment approach (Kock, 2015). The threshold for VIF factor values is 3 or lower than 3 (Becker, Ringle, Sarstedt \& Völckner, 2015). Hair et al. (2019) also agree with the aforementioned statement that VIF values should be 3 or lower. However, some authors accept VIF data that are below 5 or even 10 and state that values above 10 indicate harmful collinearity (O'brien, 2007).

Table 11: Collinearity Statistics

\begin{tabular}{|c|c|}
\hline & VIF \\
\hline Engagement (ENG1) & 3.166 \\
\hline Engagement (ENG2) & 3.789 \\
\hline Engagement (ENG3) & 3.268 \\
\hline Engagement (ENG4) & 3.013 \\
\hline Engagement (ENG5) & 2.708 \\
\hline Engagement (ENG6) & 2.17 \\
\hline Engagement (ENG7) & 2.245 \\
\hline Engagement (ENG8) & 2.096 \\
\hline Flexible work arrangements (FWA10R) & 1.831 \\
\hline Flexible work arrangements (FWA8R) & 1.219 \\
\hline Flexible work arrangements (FWA9R) & 1.84 \\
\hline Turnover intentions (TI1) & 3.528 \\
\hline Turnover intentions (TI2) & 3.068 \\
\hline Turnover intentions (TI3R) & 1.451 \\
\hline Turnover intentions (TI4) & 1.804 \\
\hline
\end{tabular}

Source: Authors' calculation

Multicollinearity analysis shows that the values of VIF indicators are generally lower than 3 , but that several VIF values are slightly above 3 , however, they are also accepted, based on indicators of several authors who accept VIF values that are lower than 5 or even 10.

The final step of the analysis is to investigate the relationship between the independent variable (FWA) and the two dependent variables Engagement and Turnover intentions. The data in Table 9 and Scheme 2 show the PLS-SEM ratio coefficients as well as the level of their significance. R2 as a coefficient of deviation in the observed variation of the dependent variable "Engagement" $16.7 \%$, "Turnover Intentions" $\mathrm{R}^{2}$ has a value of $18.6 \%$ and this is explained by the independent variable "FWA" in the model.

Table 12: Mean, Standard Deviation, T-statistics, P-values

\begin{tabular}{|l|c|c|c|c|c|c|c|}
\hline & & Original Sample (O) & Sample Mean (M) & Standard Deviation & T Statistics & $P$ Values & Results \\
\hline H1 & FWA $->$ Engagement & $\mathbf{0 . 4 0 9}$ & 0.418 & 0.051 & 7.981 & 0 & Accepted \\
\hline H2 & FWA $>$ Turnover intentions & -0.431 & -0.44 & 0.047 & 9.161 & 0 & Accepted \\
\hline
\end{tabular}

Source: Authors' calculation

The results in Table 9 demonstrate that all coefficients that represent the relationship between the independent reflective constructs (Flexible Work Arrangements - FWAs) and the dependent reflective construct (Engagement) are positive and statistically significant $(\boldsymbol{\beta}=0.409 ; \boldsymbol{T}=7.981 ; \boldsymbol{P}=0.000)$. Relationship between the independent reflective construct (Flexible Work Arrangements - FWAs) and dependent reflective construct (Turnover intentions) is a negative and statistically significant relationship ( $\beta$ $=-0.431 ; T=9.161 ; P=0.000)$. 


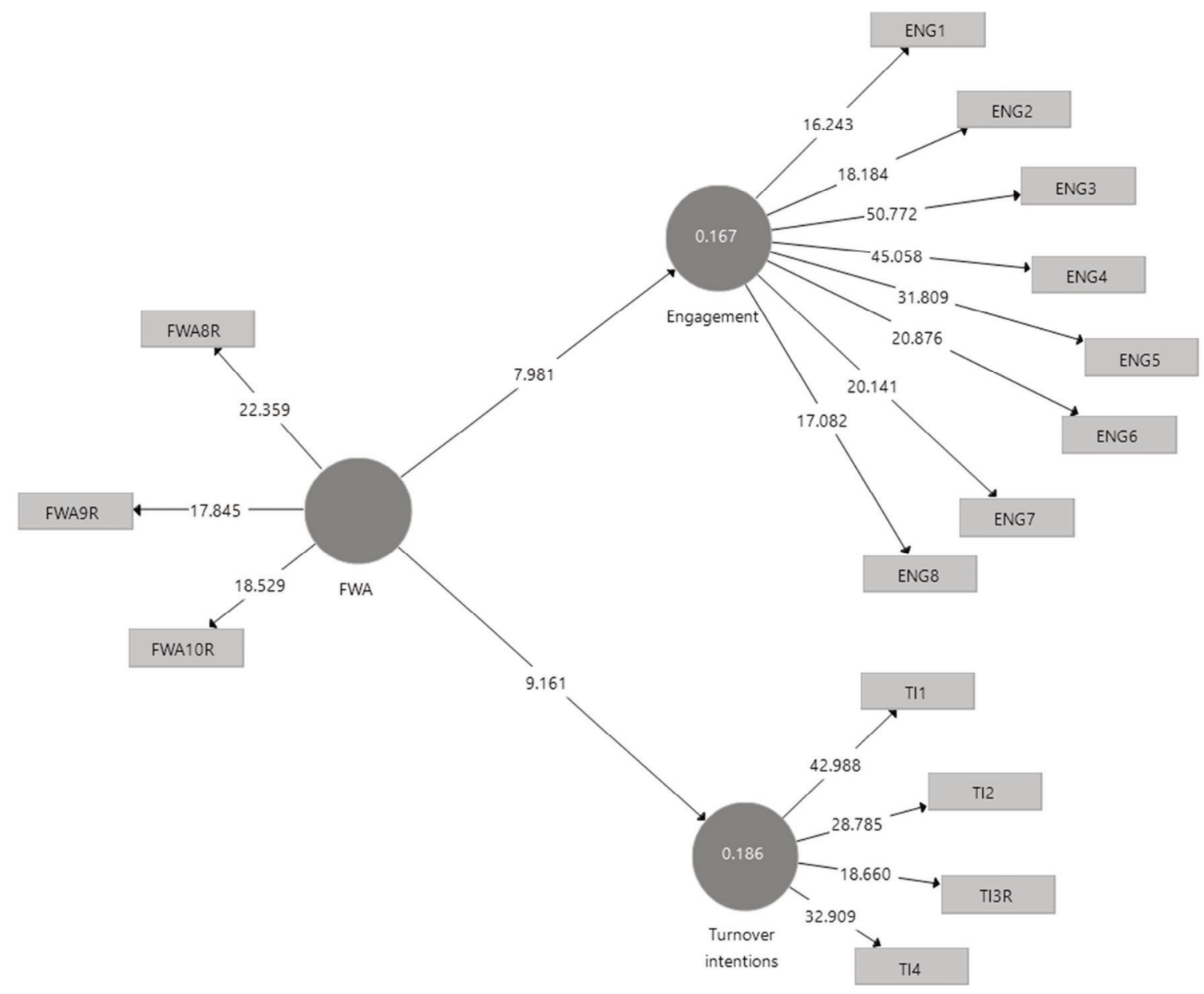

Figure 2: The path model with bootstrapping results Source: Authors' calculation

Based on the abovementioned results, both hypotheses stated in this research are confirmed.

The subject of the research refers to the impact of FWAs on the behavior of employees during the COVID-19 pandemic in the Republic of Serbia. The purpose of the research is to determine the impact of the COVID-19 pandemic and the change in the traditional way of doing business on a new type by applying FWAs to Engagement and Turnover intentions. Based on the results obtained using Smart PLS 3 software, the research showed that all hypotheses were confirmed and that FWAs positively affected employee engagement. As for the intention to leave, Flexible Work Arrangements have shown that they negatively affect this dependent variable, which is a valuable indicator because, during the transition from business to work from home, there were many fears about how employees will manage their business, whether they will manage to do everything, tasks assigned to them, whether they will lose motivation if they work from home but research has shown that employees are suited to this way of doing business and plan to stay longer in the company to advance their careers.

Cronbach's alpha ranges between 0.732 (FWA) and 0.917 (Engagement). Hair et al. (2019) recommended that Cronbach's alpha values of $0.6-0.7$ be considered the lower limit of acceptability. Values of 0.7 mean that the objects are homogeneous and only the same constant (Masrom, 2007). Cronbach's alpha reliability over 0.8 is considered very good (Nunnalli, 1978). The value of the Composite reliability of constructs (CR) ranges from 0.842 (FWA) to 0.932 (Engagement). The lowest acceptability limit for Composite reliability of constructs (CR) is 0.7 and based on this value we conclude that the results shown in Table 7 indicate that the criterion (CR) is met. AVE (Average Variance Extracted) ranges between 0.633 (Engagement) and 0.689 (Turnover intentions). The accepted lower limit of acceptability is 0.5 (Fornell \& Lacker, 1981) On 
the ram of this lower limit, we conclude that Convergent validity satisfied in all three constructions. The discriminant validity is satisfied in Table because the value of the AVE root on the diagonal is higher than all values below for each variable shown. The value of $\boldsymbol{H T M T}$ ratios below 0.9 indicates that the defined components differ sufficiently from each other which means that they describe different phenomena. The results presented in Table 10 show that all values are below 0.9 , so we can conclude that the criterion of discriminant validity is met. Based on the results obtained from Table 11 we conclude that the values are Collinearity Statistics as prescribed and that most are below three while a few are above. All connections between independent variables and dependent ones are positive and statistically significant except for the relationship between FWA and employee intention, but the fact that it is a negative relationship does not mean that it is a bad indicator; on the contrary, it is a great result! The research showed that it was successful and that the employees managed to quickly harmonize their business and private obligations by applying modern ways of working. It is expected that in the future, this way of working will be unharmed and that it will result in the best possible business success of companies around the world.

Based on research by various authors such as Ugargol \& Patrick (2018); Weideman \& Hofmeyr (2020); Richman, Civian, Shannon, Hill \& Brennan (2008), found that FWAs positively related to employee engagement, which was confirmed in this study. In the research of the author Ugargol \& Patrick (2018), the study showed that the application of flexible options to employees had potential benefits and that this type of arrangement provides work-life balance for employees. In the work of the author Weideman \& Hofmeyr (2020) it was found that the application of flexible work arrangements had a positive impact on employee engagement and lead to increased productivity, increased employee satisfaction, improved financial performance, etc. Based on research by Richman, Civian, Shannon, Hill \& Brennan (2008), the results indicate that perceived flexibility and supportive work-life policies have significant independent effects in predicting employee engagement and expected retention even after controlling for several personal, family, and job characteristics. In the presented research on the topic "The Influence of Flexible Work Arrangement on Employee Behavior during the Covid-19 Pandemic in the Republic of Serbia", it was determined that FWAs had a positive impact on employee engagement, and these results were obtained using Smart PLS-3 software. Workers are more engaged if they have the FWAs offered by the company. Based on the conducted research, it was determined that FWAs negatively affect the turnover intention, as shown in this research. The results of the study coincide with other studies by authors who investigated the impact of FWA on turnover intentions, so studies involving Anglo samples showed that FWA availability was negatively associated with turnover intentions (Allen, 2001; Batt \& Valcour, 2003; McNall et al., 2010; Berkery et al., 2020). In the work of the author Allen (2001), it was found that flexible benefits were positively related to job satisfaction and negatively related to turnover intentions. Based on the research of the author Batt \& Valcour (2003), it was determined that flextime availability is in negative relation with turnover intentions. McNall et al. (2010) found that flextime and compressed workweek availability were negatively related to the intention to leave. Based on research by Berber \& Slavic (2019) in "Flexible Working Arrangements and Employee Turnover in Central and Eastern Europe" they found that the FWA bundle that consists of home-based work and teleworking had a negative attitude towards employees' turnover which means that a more extensive usage of this kind of FWAs reduced employees decision to leave a company. Also, Berkery et al. (2020) found that flexible working time is negatively related to turnover intentions in 1,064 private sector organizations from France, Germany, Hungary, Ireland, Italy, Sweden, and the United Kingdom. Based on the research of Ramos and Prasetyo (2020), the results showed that "Work from home" increases the "Productivity" of the employee and reduces the "Job performance". As for "Stress at work", it indirectly reduces "Productivity" and directly increases the "Job performance". In the research of the authors Halkos and Bousinakis (2010) it has been proven that stress leads to a decrease in productivity while increasing employee satisfaction at work contributes to increasing employee productivity. If the job starts with activities which collide with the personal life of the worker, it leads to a negative effect on productivity. Quality work is more related to savings and personal satisfaction than to workload. Energy employed workers have a positive impact on productivity.

Empirical implications. The application of flexible working arrangements in the Republic of Serbia would have great benefits, as shown by research conducted based on completed questionnaires on the application of flexible working arrangements in companies during the COVID-19 pandemic. Workers need to be aware of the benefits of this type of business so that they can use them in the best possible way and make their business easier and thus contribute to the success of the company in which they work. After the theoretical acquaintance of workers with the possibilities of using FWAs and their advantages, we move on to the practical application of this type of business. Companies need to carefully plan and implement FWAs because hiring relationships are positive which tends to raise the level of engagement but also negative relationships with turnover intentions, which means employees are less willing to leave the company they work with.

Limitation of the research is related to a relatively small sample, but therefore the analysis performed by SMART PLS confirmed the validity of the database and results. Some of the suggestions for future research are to increase the number of respondents who use flexible work arrangements in their business and to pay more attention to teleworking and homebased work to make the company's business success greater and thus employee satisfaction higher because the essence of any business is to have workers who enjoy the work they do and feel relieved and creatively contribute to the success of the company in which they work, creating a balance between their private and business life. The essence is that each side is satisfied and that the work is done in the best possible way to remain competitive and ahead of the others. 


\section{REFERENCES}

[1] Ab Hamid, M. R., Sami, W., \& Sidek, M. M. (2017). Discriminant validity assessment: Use of Fornell \& Larcker criterion versus HTMT criterion. Journal of Physics: Conference Series, (1), p. 890. DOI: $10.1088 / 1742-6596 / 890 / 1 / 012163$

[2] Albion, M. J. (2004). A Measure of Attitudes Towards Flexible Work Options. Australian Journal of Management, 29(2), 285. DOI: 10.1177/031289620402900207

[3] Allen, T.D. (2001). Family-supportive work environments: The role of organizational perceptions. Journal of Vocational Behavior, 58, 414-435 DOI: 10.1006/jvbe.2000.1774.

[4] Anderson, A. J., Kaplan, S. A., \& Vega, R. P. (2015). The impact of telework on emotional experience: When, and for whom, does telework improve daily affective well-being?. European Journal of Work and Organizational Psychology, 24(6), 882-897.

[5] Anderson, D. and Kelliher, C. (2009). Flexible working and engagement: The importance of choice. Strategic Harvard Business Review, 8(2), 13-18 DOI: 10.1108/14754390910937530

[6] Azar, S., Khan, A., \& Van Eerde, W. (2018). Modeling linkages between flexible work arrangements' use and organizational outcomes. Journal of Business Research, 91, 134-143. DOI: 10.1016/j.jbusres.2018.06.004

[7] Bakker, A. B., \& Demerouti, E. (2007). The job demands resources model: State of the art. Journal of managerial psychology. DOI: 10.1108/02683940710733115

[8] Baruch, Y. (2000), "Teleworking: benefits and pitfalls as perceived by professionals and managers", New Technology, Work and Employment, 15(1), 35. DOI: 10.1111/1468-005X.00063

[9] Batt, R., \& Valcour, P.M. (2003). Human resources practices as predictors of work-family outcomes and employee turnover. Industrial Relations, 42, 189-220. DOI:

[10] Becker, J.-M., Ringle, C.M., Sarstedt, M. and Völckner, F. (2015), How collinearity affects mixture regression results. Marketing Letters, 26 (4), 643-659. DOI: 10.1007/s11002-014-9299-9

[11] Berber, N., \& Slavic, A. (2019) Flexible Working Arrangements and Employee Turnover in the Central and Eastern Europe. Knowledge Economy Society, 35-36. DOI: 10.1080/09585192.2016.1277364

[12] Berber, N., Slavic, A., \& Aleksic, M. (2020). Relationship between Perceived Teamwork Effectiveness and Team Performance in Banking Sector of Serbia. Sustainability, 12(20), 9. DOI: 10.3390/su12208753

[13] Berkery, E., Morley, M. J., Tiernan, S., \& Peretz, H. (2020). From start to finish: Flexi-time as a social exchange and its impact on organizational outcomes. European Management Journal, 38(4), p. 591-601. DOI: 10.1016/j.emj.2020.02.003

[14] Bjekic, R., Jelaca, M. S., Berber, N., \& Aleksic, M. (2020). Factors Affecting Entrepreneurial Intentions of Faculty Students. Management: Journal of Sustainable Business and Management Solutions in Emerging Economies. Forthcoming article DOI: 10.7595/management.fon.2020.0024

[15] Boone, H. N., \& Boone, D. A. (2012). Analyzing Likert data. Journal of extension, 50(2), 1. Retrieved from https://joe.org/joe/2012april/tt2.php

[16] Caligiuri, P., De Cieri, H., Minbaeva, D., Verbeke, A., \& Zimmermann, A. (2020). International HRM insights for navigating the COVID-19 pandemic: Implications for future research and practice. DOI: 10.1057/s41267-020-00335-9.

[17] Chen, Y., \& Fulmer, I. S. (2018). Fine-tuning what we know about employees' experience with flexible work arrangements and their job attitudes. Human Resource Management, 57(1), 381-395. DOI: 10.1002/hrm.21849

[18] Chen, Z. X., \& Francesco, A. M. (2000). Employee demography, organizational commitment, and turnover intentions in China: do cultural differences matter?. Human Relations, 53(6), 876. DOI: $10.1177 / 0018726700536005$.

[19] Chin, W. W. (1998). The partial least squares approach to structural equation modeling. Modern methods for business research, 295(2), 295-336. Retrieved from http://www.researchgate.net/publication/232569511

[20] Choo, J. L. M., Desa, N. M., \& Asaari, M. H. A. H. (2016). Flexible working arrangement toward organizational commitment and work-family conflict. Studies in Asian Social Science, 3(1), 21-36. DOI: 10.5430/sass.v3n1p21

[21] Dakduk, S., González, Á., \& Portalanza, A. (2019). Learn About Structural Equation Modeling in SmartPLS With Data From the Customer Behavior in Electronic Commerce Study in Ecuador (2017). SAGE Publications, Limited. DOI: 10.4135/9781526498205

[22] Den Dulk, L., Groeneveld, S., Ollier-Malaterre, A., \& Valcour, M. (2013). National context in work-life research: A multi-level cross-national analysis of the adoption of workplace work-life arrangements in Europe. European Management Journal, 31, 478-494. DOI: 10.1016/j.emj.2018.01.007

[23] Fathi, A., Nikbakhsh, R., Khaki, A. A., \& Sharififar, F. (2020). Assessment Factors Related to Turnover Intention in Sports Organizations.Journal of Health Promotion Management, 9(1), 33-41 DOI: 10.21859/jhpm-08014

[24] Fornell, C., \& Larcker, D. F. (1981). Evaluating structural equation models with unobservable variables and measurement error. Journal of marketing research, 18(1), 39-50. DOI: 10.1177\%2F002224378101800104

[25] Grover, S.L. and Crooker, K.J. (1995). Who appreciates family responsive human resource policies: The Impact of family friendly policies on the organizational attachment of parents and non parents? Personnel Psychology, 48(2), 271-288. DOI: 10.1111/j.1744-6570.1995.tb01757.x 
[26] Grubor, A., Berber, N., Aleksic, M., \& Bjekic, R. (2020). The influence of corporate social responsibility on organizational performance: A research in AP Vojvodina. Anali Ekonomskog fakulteta u Subotici, (43), 313. DOI: $10.5937 / A n E k S u b 2001003 G$

[27] Hair, J. F. J., Sarstedt, M., Hopkins, L., \& Kuppelwieser, V. G. (2014). Partial least squares structural equation modeling (PLS-SEM). European Business Review, 26(2), 7. DOI: 10.1108/EBR-10-2013-0128

[28] Hair, J. F., Risher, J. J., Sarstedt, M., \& Ringle, C. M. (2019).When to use and how to report the results of PLS-SEM. European Business Review, 31(1), 15. DOI: 10.1108/EBR-11-2018-0203

[29] Halkos, G., \& Bousinakis, D. (2010). The effect of stress and satisfaction on productivity. International Journal of Productivity and Performance Management. DOI: 10.1108/17410401011052869

[30] Hammer, L., Neal, M., Newsom, J., Brockwood, K., \& Colton, C. (2005). A Longitudinal Study of the Effects of Dual-Earner Couples' Utilization of Family-Friendly Workplace Supports on Work and Family Outcomes. Journal of Applied Psychology, 90(4), 799-810. DOI: 10.1037/0021-9010.90.4.799

[31] Heleta, M. (2010). Projektovanje menadžment sistema životne i radne sredine. Univerzitet Singidunum, 16. DOI: $10.1111 / 1468-232 X .00287$

[32] Kahn, W. A., \& Heaphy, E. D. (2014). Relational contexts of personal engagement at work. Employee engagement in theory and practice, p. 82-96.

[33] Kock, N. (2015). Common method bias in PLS-SEM: A full collinearity assessment approach. International Journal of e-Collaboration, 11(4), 1-10. DOI: 10.4018/ijec.2015100101

[34] Kossek, E. E., \& Lautsch, B. A. (2018). Work-life flexibility for whom? Occupational status and work-life inequality in upper, middle, and lower-level jobs. Academy of Management Annals, 12(1), 5-36. DOI: 10.5465/annals.2016.0059

[35] Laurel A. McNall, Aline D. Masuda \& Jessica M. Nicklin (2009) Flexible Work Arrangements, Job Satisfaction, and Turnover Intentions: The Mediating Role of Work-to-Family Enrichment, The Journal of Psychology, 144:1, 61-81, DOI: 10.1080/0022398093356073

[36] Lutfiani Putri Windia, N. M. A., Singh, J. S. K., Rashid, T. A., \& Arumugam, T. (2020). Reducing Turnover Intention through Flexible Work Arrangement, Supervisor Support, and Employee Engagement: A Study among Female Auditors in Jakarta. Global Business \& Management Research, 12(3).

[37] Masrom, M. (2007). Technology acceptance model and e-learning. Technology, 21(24), 81.

[38] Masuda, A. D., Poelmans, S. A. Y., Allen, T. D., Spector, P. E., Lapierre, L. M., Cooper, C. L., ... MorenoVelazquez, I. (2011). Flexible Work Arrangements Availability and their Relationship with Work-to-Family Conflict, Job Satisfaction, and Turnover Intentions: A Comparison of Three Country Clusters. Applied Psychology, 61(1), 18. DOI: 10.1111/j.1464-0597.2011.00453.x

[39] McNall, L.A, Masuda, A.D., \& Nicklin, J.M. (2010). Flexible work arrangements and job satisfaction/turnover intentions: The mediating role of work-to-family enrichment. Journal of Psychology: Interdisciplinary \& Applied, 1-21. DOI: 10.1080/00223980903356073

[40] Myers, V. L., \& Dreachslin, J. L. (2007). Recruitment and retention of a diverse workforce: Challenges and opportunities. Journal of Healthcare Management, 52(5), 290-298.

[41] Nunnally, J.C. (1978). Psychometric Theory, (2nd ed.). New York: McGraw-Hill.

[42] O'brien, R. M. (2007). A Caution Regarding Rules of Thumb for Variance Inflation Factors. Quality \& Quantity, 41(5), 688. DOI: 10.1007/s11135-006-9018-6

[43] OCDE, O. (2020). Employment Outlook 2020: Worker Security and The Covid-19 Crisis, 24.

[44] Parkes, L. P., \& Langford, P. H. (2008). Work-life balance or work-life alignment? A test of the importance of work-life balance for employee engagement and intention to stay in organisations. Journal of Management \& Organization, 14(3), 267-284.

[45] Peterson, R. A., \& Kim, Y. (2013). On the Relationship Between Coefficient Alpha and Composite Reliability. Journal of Applied Psychology, 98(1), 194-198. DOI: 10.1037/a0030767

[46] Pigini, C., \& Staffolani, S. (2019). Teleworkers in Italy: who are they? Do they make more?. International Journal of Manpower, 40(2), 265-285. DOI: 10.1108/IJM-07-2017-0154

[47] Prasetyo, Y. T., Castillo, A. M., Salonga, L. J., Sia, J. A., \& Seneta, J. A. (2020). Factors affecting perceived effectiveness of COVID-19 prevention measures among Filipinos during enhanced community quarantine in Luzon, Philippines: Integrating Protection Motivation Theory and extended Theory of Planned Behavior. International journal of infectious diseases, 99, 312-323. DOI: 10.1016/j.jij. 2020.07.074

[48] Ramos, J. P., \& Prasetyo, Y. T. (2020). The Impact of Work-Home Arrangement on the Productivity of Employees during COVID-19 Pandemic in the Philippines: A Structural Equation Modelling Approach. In ACM International Conference Proceeding Series. DOI::10.1145/3429551.3429568

[49] Richardson, J., \& McKenna, S. (2014). Reordering spatial and social relations: A case study of professional and managerial teleworkers. British Journal of Management, 25, 724, DOI: 10.1111/1467-8551.12017

[50] Richman, A. L., Civian, J. T., Shannon, L. L., Hill, J. E., \& Brennan, R. T. (2008). The relationship of perceived flexibility, supportive work-life policies, and use of formal flexible arrangements and occasional flexibility to employee engagement and expected retention. Community Work \& Family, 11, 183-197. DOI: $10.1080 / 13668800802050350$

[51] Schaufeli, W. B., Bakker, A. B., \& Salanova, M. (2006). The Measurement of Work Engagement with a Short Questionnaire. Educational and Psychological Measurement, 66(4), 714. DOI: 10.1177/0013164405282471 
[52] Sharafizad, F., Paull, M., \& Omari, M. (2011). Flexible Work Arrangements: Accessibility in a University Environment. Australian Universities' Review, 53(2), 43-49.

[53] Spurk, D., \& Straub, C. (2020). Flexible employment relationships and careers in times of the COVID-19 pandemic. DOI: 10.1016/j.jvb.2020.103435.

[54] Stavrou, E.T., Parry, E., \& Anderson, D. (2015). Nonstandard Work Arrangements and Configurations of Firm and Societal Systems. "e International Journal of Human Resource Management, 26(19), 2412-2433, DOI: 10.1080/09585192.2014.992456.

[55] Stirpe \& Zárraga-Oberty, (2017). Are high-performance work systems always a valuable retention tool? The roles of workforce feminization and flexible work arrangements. European Management Journal, 35, 128136. DOI: 10.1016/j.emj.2016.04.002

[56] Tavares, F., Santos, E., Diogo, A., \& Ratten, V. (2020). Teleworking in Portuguese communities during the COVID-19 pandemic. Journal of Enterprising Communities: People and Places in the Global Economy. DOI: 10.1108/JEC-06-2020-0113

[57] Thulin, E., Vilhelmson, B., \& Johansson, M. (2019). New telework, time pressure, and time use control in everyday life. Sustainability, 11(11), 3067. DOI: 10.3390/su11113067

[58] Timms, C., Brough, P., O'Driscoll, M., Kalliath, T., Siu, O.L., Sit, C. and Lo, D. (2015). Flexible work arrangements, work engagement, turnover intentions, and psychological health. Asia Pacific Journal of Human Resources, 53(1), 83-103. DOI: 10.1111/1744-7941.12030

[59] Ugargol, J. D., \& Patrick, H. A. (2018). The Relationship of Workplace Flexibility to Employee Engagement among Information Technology Employees in India. South Asian Journal of Human Resources Management, 5(1), 12. DOI: 10.1177/2322093718767469

[60] Vasic, M. (2020). Challenges of teleworking during the Covid-19 pandemic. Anali Ekonomskog Fakulteta u Subotici, 56(44), 64. DOI: 10.5937/AnEkSub2044063V

[61] Wang, B., Liu, Y., Qian, J., \& Parker, S. K. (2020). Achieving effective remote working during the COVID19 pandemic: A work design perspective. Applied Psychology, 530. Doi: 10.1111/apps.12290

[62] Weideman, M., \& Hofmeyr, K. (2020). The influence of flexible work arrangements on employee engagement: An exploratory study. DOI: 10.4102/sajhrm.v18i0.1209

[63] Wheatley, D. (2017). Employee satisfaction and use of flexible working arrangements. Work, Employment and Society, 31(4), 567-585. DOI: 10.1177\%2F0950017016631447

[64] World Health Organization (2020), "Coronavirus disease (COVID-19) pandemic", Retrieved from (Date of access 01.03.2021) https://www.who.int/

Received: 2021-02-22

Revision requested: 2021-04-08

Revised: 2021-05-27 (2 revisions)

Accepted: 2021-05-31

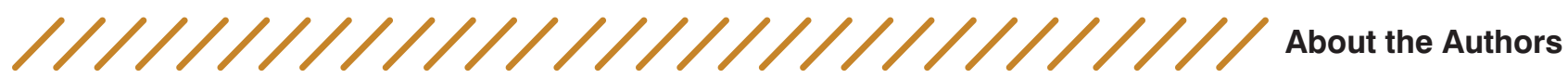

Dimitrije Gašić

University of Novi Sad - Faculty of Economics in Subotica, Serbia dimitrijegasic33@gmail.com

Dimitrije Gašić is a Ph.D. student at the Faculty of Economics in Subotica, University of Novi Sad, the Republic of Serbia. Department „Business Economy and Management" module Entrepreneurial Management.

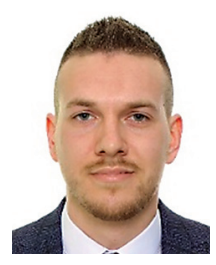

\section{Nemanja Berber \\ University of Novi Sad, Faculty of Economics in Subotica, Serbia nemanja.berber@ef.uns.ac.rs}

Nemanja Berber is an Assistant Professor at the Faculty of Economics in Subotica, the

University of Novi Sad, the Republic of Serbia. He is engaged in the areas of human resource management, organisational behaviour, urban management, and environmental management. His research interests include human resource management practice in Serbia and Central and Eastern European regions, especially employees' compensation, benefits, and training. He participates in CRANET (The Cranfield Network on International Human Resource Management) and CEEIRT (The Central and Eastern European International Research Team) projects on HRM and IHRM.

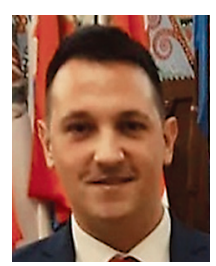

